\title{
EPIDEMIOLOGI MEROKOK PADA SISWA KELAS 7 DAN 8 SMPN 33 KOTA PEKANBARU
}

\author{
Agus Alamsyah, Nurvi Susanti \\ Pusat Penelitian dan Pengabdian STIKes Hang Tuah Pekanbaru \\ Prodi Ilmu Kesehatan Hang Tuah Pekanbaru \\ e-mail:agusa41@gmail.com
}

\begin{abstract}
Epidemiology smoke are of science that studies distribution, the frequency and determinan someone or some group to behave smoking. Interviews with any one teacher SMPN 33 Pekanbaru say a lot of their students who company to smoking habit good students men and women. Research aims to know the proportion and determinan to behavior smoked on the students SMPN 33 Pekanbaru. Research is quantitative analytic with design cross-sectional. Population is the class 7 and 8 smpn 33 the City of Pekanbaru were 324 people with sample the total population. The results of the study obtained that the proportion of students who smoke in SMPN 33 the City of Pekanbaru is it was found that 89 people (27.5\%) of 324 people. Variable knowledge on smoking $(p=0,000)$, cigarette advertisement $(p=0,009)$, family smoking $(p=0,022)$ their peers smoking $(p=0,009)$ and cigarette advertisement $(p=0,001)$ related to behavior smoking students SMPN 33 the City of Pekanbaru .knowledge, cigarette advertisement, family smoking, their peers smokers and pocket money is determinan behavior smoking students SMPN 33 the City of Pekanbaru.
\end{abstract}

Keywords: Smoking epidemiology, knowledge, advertising

\section{PENDAHULUAN}

Epidemiologi merokok adalah ilmu yang mempelajari distribusi, frekuensi dan faktor yang memengaruhi seseorang atau kelompok tertentu untuk berperilaku merokok. Merokok adalah suatu kegiatan atau aktivitas membakar rokok, menghisap dan menghembuskannya keluar sehingga dapat menimbulkan asap yang dapat terhisap oleh orang-orang disekitarnya. ${ }^{1}$ Merokok sangatlah merugikan kesehatan terutama pada perokok itu sendiri, karena dengan menghisap rokok maka seseorang juga mengisap bahan kimia yang kurang lebih tercatat sekitar 4.000 bahan kimia, seperti nikotin, gaskarbon, nitrogen oksida, benzene, methanol, acrolein, dan sebagainya. ${ }^{2}$

Merokok merupakan masalah yang belum bisa terselesaikan hingga saat ini dan merupakan suatu masalah fenomenal yang telah melanda semua kalangan terutama kalangan remaja. ${ }^{3}$ Remaja merupakan masa-masa transisi dari anak-anak menuju dewasa, ditandai dengan perubahan hormonal serta pencarian jati diri. Setiap perilaku dan kebiasaan yang terlihat saat dewasa biasanya dimulai pada usia dini. Salah satu perilaku tersebut adalah merokok. ${ }^{4}$

Survei yang dilakukan oleh World Health Organizatio (WHO)_ pada tahun 2014, diperkirakan kematian remaja pada tahun 2030 mencapai 10 juta orang per tahunnya dan jumlah perokok di dunia meningkat hampir satu miliar. Berdasarkan survei Demografi Universitas Indonesia tahun 2009 sebanyak 427.948 orang remaja di Indonesia meninggal per tahunnya akibat berbagai penyakit yang disebabkan oleh rokok. ${ }^{5}$

Indonesia menempati urutan kelima di dunia dengan jumlah perokok terbanyak pada tahun 2009 setelah Rusia, Jepang, Turki dan Cina yakni berjumlah 61 juta perokok (43\% penduduk). Indonesia menepati urutan ke-2 perokok pria terbesar di dunia. ${ }^{6}$ Perilaku merokok penduduk 15 tahun ke atas masih belum terjadi penurunan dari tahun 2007 ke 2013, cenderung meningkat dari $34,2 \%$ tahun 2007 menjadi 36,3\% tahun 2013 dan 20\% nya adalah remaja. Terdapat $64,9 \%$ laki-laki dan $2,1 \%$ perempuan masih menghisap rokok tahun 2013. Rata-rata jumlah batang rokok yang dihisap adalah sekitar 12,3 batang perharinya, bervariasi dari yang terendah 10 batang di Yogyakarta dan tertinggi di Bangka Belitung 18,3 batang dan di Riau 16-17 batang perharinya. Proporsi penduduk berumur $>10$ tahun yang merokok di Provinsi Riau, yaitu $28,3 \%{ }^{7}$ 
Berdasarkan hasil wawancara dengan salah satu guru di SMPN 33 Pekanbaru mengatakan bahwa banyak siswa yang mempunyai kebiasaan merokok. Kebiasaan merokok bukan hanya pada siswa laki-laki, tetapi ada juga pada siswa perempuan. Dari 20 siswa yang diwawancarai ada 14 siswa yang mempunyai kebiasaan merokok 4 diantaranya adalah perempuan. Siswa merokok pada saat jam istirahat yang dilakukan di luar pekarangan sekolah, tetapi ada juga siswa yang berani merokok di dalam ruangan kelas. SMPN 33 Pekanbaru terletak dipinggir kota dan di SMPN 33 belum pernah dilakukan penelitian tentang merokok. Penelitian ini bertujuan mengetahui epidemiologi (proporsi dan determinan/faktor yang mempengaruhi) merokok pada siswa/i kelas 7 dan 8 SMPN 33 Pekanbaru.

\section{METODOLOGI PENELITIAN}

Jenis penelitian adalah kuantitatif analitik observasional dengan desain cross sectional. Penelitian dilaksanakan di SMPN 33 Kota Pekanbaru pada tanggal 12 Maret sampai dengan 02 April 2016. Populasi penelitian adalah siswa-siswi kelas 7 dan 8 SMPN 33 Kota Pekanbaru berjumlah 324 orang. Seluruh populasi dijadikan sampel dalam penelitian ini, dengan kriteria inklusi, yaitu hadir pada saat penelitian dilakukan dan siswa-siswi tersebut bersedia menjadi responden. Kriteria eksklusi, yaitu siswa-siswi Kelas 9 SMPN 33 Kota Pekanbaru. Pengumpulan data dilakukan dengan wawancara menggunakan kuesioner. Analisis data univariat dan bivariat, untuk variabel independen (pengetahuan, iklan rokok, ayah perokok, dan teman sebaya perokok) dengan menggunakan uji chi square sedangkan untuk variabel independen uang saku siswa menggunakan uji $\mathrm{t}$ karena datanya dalam bentuk numerik. Data disajikan dalam bentuk tabel disertai narasi.

\section{HASIL DAN PEMBAHASAN}

\section{Hasil}

Tabel 1 menunjukan responden banyak yang berjenis kelamin laki-laki, yaitu 176 orang $(54,3 \%)$ dibandingkan jenis kelamin perempuan. Responden yang kelas 8 sebanyak 164 orang $(50,4 \%)$.

\section{Tabel 1. Karekteristik Subjek Penelitian}

\begin{tabular}{llll}
\hline No & $\begin{array}{l}\text { Variabel } \\
\text { Independen }\end{array}$ & Frekuensi & Persentase \\
\hline $\mathbf{1}$ & Jenis Kelamin & & \\
& Laki-laki & 176 & 54,3 \\
& Perempuan & 148 & 45,7 \\
& Total & 324 & 100 \\
$\mathbf{2}$ & Kelas & & \\
& Tujuh (7) & 160 & 49,6 \\
& Delapan (8) & 164 & 50,4 \\
& Total & 324 & 100 \\
\hline
\end{tabular}

Sumber: Data Primer, 2016

Tabel 2. Karekteristik Subjek Penelitian berdasarkan umur dan uang saku

\begin{tabular}{llll}
\hline Variabel & Mean & Minimum & Maksimum \\
\hline Umur & 13,6 & 12 & 16 \\
Uang Saku & 8230 & 500 & 150.000 \\
(dalam & & & \\
Rupiah) & & & \\
Sumber: Data Primer, 2016 &
\end{tabular}

Tabel 2 diketahui rata-rata subjek penelitian berumur 13,6 tahun dengan umur termuda 12 tahun dan umur tertua 16 tahun. Rata-rata uang saku siswa/i SMPN 33 Kota Pekanbaru adalah Rp 8230, 00. Paling kecil uang jajannya adalah Rp 500,00 dan paling besar Rp.150.000,00.

Tabel 3. Hasil Analisis Univariat Variabel Dependen dan Independen

\begin{tabular}{|c|c|c|c|}
\hline No & $\begin{array}{l}\text { Variabel } \\
\text { Independen }\end{array}$ & Frekuensi & Persentase \\
\hline 1 & Perilaku & & \\
\hline & Merokok & & \\
\hline & Merokok & 89 & 27,5 \\
\hline & Tidak & 235 & 72,5 \\
\hline & Merokok & & \\
\hline & Total & 324 & 100 \\
\hline 2 & Pengaruh & & \\
\hline & Iklan Rokok & & \\
\hline & $\mathrm{Ya}$ & 81 & 25 \\
\hline & Tidak & 243 & 75 \\
\hline & Total & 324 & 100 \\
\hline 3 & Keluarga & & \\
\hline & Merokok & & \\
\hline & $\mathrm{Ya}$ & 259 & 79,9 \\
\hline & Tidak & 65 & 20,1 \\
\hline & Total & 324 & 100 \\
\hline
\end{tabular}




\begin{tabular}{llll}
\hline No & $\begin{array}{l}\text { Variabel } \\
\text { Independen }\end{array}$ & Frekuensi & Persentase \\
\hline 4 & Teman & & \\
& Sebaya & & \\
& Merokok & & \\
& Ya & 223 & 68,8 \\
& Tidak & 101 & 31,2 \\
& Total & 324 & 100 \\
5 & Pengetahuan & & \\
& Tentang & & \\
& Rokok & & \\
& Pengetahuan & 106 & 32,7 \\
& Rendah & & \\
& Pengetahuan & 208 & 67,3 \\
& Tinggi & & \\
\hline & Total & 324 & 100 \\
\hline
\end{tabular}

Sumber: Data Primer, 2016

Hasil analisis univariat pada Tabel 3 menunjukan bahwa siswa/i SMPN 33 yang mempunyai perilaku merokok, yaitu sebesar 89 orang $(27,5 \%)$ dan sisanya 235 orang $(72,5 \%)$ tidak berperilaku merokok. Siswa/i SMPN 33 yang terpengaruh dengan iklan rokok, yaitu sebesar 81 orang (25\%), keluarga yang merokok sebesar 259 orang (79,9\%), memiliki teman sebaya merokok, yaitu 223 orang $(68,8 \%)$ dan yang memiliki pengetahuan rendah tentang rokok sebesar 106 orang $(32,7 \%)$.

Tabel 4. Hasil Analisis Bivariat

\begin{tabular}{|c|c|c|c|c|c|}
\hline \multirow{3}{*}{$\begin{array}{l}\text { Variabel Independen dan } \\
\text { Kategori }\end{array}$} & \multicolumn{2}{|c|}{ Perilaku Merokok } & \multirow{3}{*}{\multicolumn{2}{|c|}{$\begin{array}{cc}\text { Jumlah } & \mathbf{P} \\
& \text { Value }\end{array}$}} & \multirow{3}{*}{$\begin{array}{c}\text { POR } \\
(95 \% \mathrm{CI})\end{array}$} \\
\hline & Merokok & $\begin{array}{c}\text { Tidak } \\
\text { Merokok } \\
\end{array}$ & & & \\
\hline & n (\%) & n (\%) & & & \\
\hline \multicolumn{6}{|l|}{ Pengaruh Iklan Rokok } \\
\hline $\mathrm{Ya}$ & $75(92,6)$ & $6(7,4)$ & $81(100)$ & \multirow{2}{*}{0,000} & $4(75,8-$ \\
\hline Tidak & $14(71,7)$ & $229(94,2)$ & $243(100)$ & & $550,9)$ \\
\hline Total & $89(27,5)$ & $235(72,5)$ & $324(100)$ & & \\
\hline \multicolumn{6}{|l|}{ Keluarga Merokok } \\
\hline $\mathrm{Ya}$ & $79(30,5)$ & $180(69,5)$ & $259(100)$ & \multirow{2}{*}{0,022} & $2,4(1,170-$ \\
\hline Tidak & $10(15,4)$ & $55(84,6)$ & $65(100)$ & & $4,978)$ \\
\hline Total & $89(27,5)$ & $235(72,5)$ & $324(100)$ & & \\
\hline \multicolumn{6}{|l|}{ Teman Sebaya Merokok } \\
\hline $\mathrm{Ya}$ & $81(36,3)$ & $142(63,7)$ & $223(100)$ & \multirow{3}{*}{0,001} & $-14,3)$ \\
\hline Tidak & $8(7,9)$ & $93(92,1)$ & $101(100)$ & & \\
\hline Total & $89(27,5)$ & $235(72,5)$ & $324(100)$ & & \\
\hline \multicolumn{6}{|l|}{ Pengetahuan Tentang Rokok } \\
\hline Pengetahuan Rendah & $83(78,3)$ & $23(21,7)$ & $88(100)$ & \multirow{3}{*}{0,001} & $127,5(50,1-$ \\
\hline Pengetahuan Tinggi & $6(2,8)$ & $212(97,2)$ & $92(100)$ & & \\
\hline Total & $89(27,5)$ & $235(72,5)$ & $324(100)$ & & \\
\hline
\end{tabular}

Sumber: Data Primer, 2016

Tabel 5. Hasil Analisis Bivariat Uji T Independen Variabel Uang Saku

\begin{tabular}{lllcc}
\hline Variabel & $\begin{array}{l}\text { Perilaku } \\
\text { Merokok }\end{array}$ & Mean & SD & $\begin{array}{c}\text { P. } \\
\text { Value }\end{array}$ \\
\hline Uang & Merokok & 12505 & 13357 & 0,001 \\
Saku & Tidak & 6610 & 11506 & \\
& Merokok & & & \\
\hline
\end{tabular}

Sumber: Data Primer, 2016

Hasil analisis bivariat menggunakan uji chi square pada Tabel 4 menunjukan bahwa pengetahuan tentang rokok $(\mathrm{p}=0,000 ; \mathrm{POR}=44,59 ; \mathrm{CI} 95 \%=13,68-145,28)$, iklan rokok $(\mathrm{p}=0,009 ; \mathrm{POR}=33,44 ; \mathrm{CI} 95 \%=$ 9,91-112,8) teman sebaya merokok $(\mathrm{p}=0,009 ; \mathrm{POR}=5,93 ; \mathrm{CI} 95 \%=1,54-22,79)$, keluarga

merokok $(p=0,022 ; P O R=2,4 ; C I 95 \%=1,170-4,978)$

berhubungan dengan perilaku merokok. Analisis bivariat variabel uang saku menggunakan uji t pada Tabel 5 menunjukan bahwa didapatkan nilai $\mathrm{p}=0,001$, berarti pada alpha 5\% terlihat ada perbedaan yang signifikan rata-rata uang saku antara siswa/i yang merokok dengan siswa/i yang tidak merokok.

\section{Pembahasan}

Dari hasil penelitian terdapat hubungan antara pengetahuan tentang rokok dengan perilaku merokok pada siswa/i SMPN 33 Kota Pekanbaru. Siswa/i dengan pengetahuan rendah tentang rokok maka berisiko 44,59 kali untuk 
berperilaku merokok dibandingkan dengan siswa/i yang berpengetahuan tinggi tentang rokok. Hasil penelitian sejalan dengan penelitian Andika et al., tahun 2016 menunjukan terdapat hubungan yang bermakna antara tingkat pengetahuan dengan kejadian merokok pada siswa SMPN 1 Pariaman. ${ }^{8}$ Hasil penelitian Saputra tahun 2012 menunjukkan ada hubungan yang bermakna antara pengetahuan dengan perilaku merokok pada siswa SMP. Siswa yang berpengetahuan kurang baik berisiko 4,762 kali untuk merokok dibanding dengan siswa dengan pengetahuan baik. ${ }^{9}$ Penelitian Ali tahun 2014 menunjukan bahwa faktor pengetahuan merupakan faktor yang paling dominan yang berhubungan dengan perilaku merokok, terdapat hubungan bermakna antara pengetahuan tentang rokok dengan perilaku merokok $(p=0,005) \cdot{ }^{10}$. Hasil penelitian Alamsyah dan Novianto tahun 2016 juga menunjukan bahwa siswa laki-laki kelas $\mathrm{X}$ dan XI yang memiliki pengetahuan rendah tentang rokok berisiko 7 kali berperilaku merokok dibandingkan siswa laki-laki kelas X dan XI yang memiliki pengetahuan tinggi tentang rokok. ${ }^{11}$ Tindakan mengurangi jumlah konsumsi rokok dapat dipengaruhi oleh tingkat pengetahuan perokok yang juga tinggi, karena tindakan perokok dapat dipengaruhi oleh pengetahuan. $^{12}$

Pengetahuan merupakan modal dasar bagi seseorang untuk berperilaku. Pengetahuan yang cukup akan memotivasi individu untuk berperilaku baik. Orang yang dipenuhi banyak pengetahuan akan mempersepsikan informasi tersebut sesuai dengan predisposisi psikologisnya. Pengetahuan yang tinggi tentang rokok pada remaja cenderung memperkecil kemungkinan remaja tersebut berperilaku merokok. Hal ini disebabkan remaja tersebut telah mengetahui bahaya atau dampak negatif yang ditimbulkan oleh rokok. ${ }^{13}$

Hasil penelitian terdapat hubungan antara iklan rokok dengan perilaku merokok pada siswa/I SMPN 33 Kota Pekanbaru. Siswa/i yang tertarik dengan iklan rokok berisiko 33,44 kali untuk berperilaku merokok dibandingkan dengan siswa/i yang tidak tertarik terhadap iklan rokok. Hal ini sejalan dengan penelitian yang dilakukan Rachmat et al., tahun 2013 yang menyatakan bahwa sebagian besar remaja berperilaku merokok karena terpengaruh media massa dan terpapar iklan rokok di televisi. ${ }^{14}$ Hasil penelitian lainnya yaitu penelitian yang dilakukan Widiansyah tahun 2014 menunjukkan bahwa ada hubungan yang signifikan antara iklan rokok terhadap perilaku merokok pada remaja. ${ }^{15}$ Penelitian Saputra tahun 2012 juga menunjukan ada hubungan yang bermakna antara iklan dengan perilaku merokok pada siswa SMP se Kecamatan Banjit Kabupaten Way Kanan. ${ }^{9}$

Media iklan berupa media televisi, sepanduk, maupun baliho, sangat memegang peranan yang besar dalam mempengaruhi remaja dalam merokok. Mudahnya mendapat informasi maupun melihat iklan-iklan tersebut secara tidak langsung mendorong para remaja untuk membeli maupun mencoba produkproduk rokok yang baru. Dengan adanya iklan maka dia tau rokok yang baru dijual di pasaran dan ingin mencobanya. ${ }^{15}$ Iklan rokok dikemas semenarik mungkin dengan mengangkat tema pertemanan, persahabatan maupun kebersamaan. Iklan rokok dibuat dengan sangat atraktif dan kreatif menyentuh sisi psikologis yang menunjukkan citra berani, macho trendi, keren, kebersamaan, santai, optimis, jantan, penuh petualangan, kreatif, kritis serta berbagai hal lain yang membanggakan dan mewakili suara hati anak muda dan remaja. Hal ini menunjukkan secara efektif mempengaruhi perilaku siswa untuk berperilaku merokok. ${ }^{16}$

Hasil penelitian terdapat hubungan antara teman sebaya yang merokok dengan perilaku merokok pada siswa/i SMPN 33 Kota Pekanbaru. Siswa/i yang memiliki teman yang merokok maka akan berisiko 5,93 kali untuk berperilaku merokok juga dibandingkan dengan siswa/i yang tidak mempunyai teman merokok. Hal ini sejalan dengan penelitian yang dilakukan Rachmat et al., tahun 2013 yang menunjukan ada hubungan yang signifikan antara faktor teman $(\mathrm{p}=0,033)$ dengan perilaku merokok responden. Berdasarkan situasi dan kondisi yang sering mendorong mereka untuk 
merokok adalah saat bersama teman yang juga perokok. ${ }^{14}$ Penelitian yang dilakukan Ramadhani dan hidayat tahun 2009 menunjukan bahwa teman sebaya secara positif mempengaruhi niat remaja merokok $(p=0,000)$ dan menjadi faktor yang paling dominan memengaruhi remaja untuk berperilaku merokok. ${ }^{17}$ Hasil penelitian Dwi tahun 2012 menunjukkan bahwa terdapat hubungan kuat antara teman sebaya dengan tindakan merokok pada mahasiswa Universitas Hasanuddin Makassar. Salah satu yang memiliki andil besar memengaruhi sikap dan perilaku adalah kelompok teman sebaya dan pasangannya. Semakin banyak remaja merokok maka semakin besar kemungkinan teman-temannya adalah perokok juga dan demikian sebaliknya. Dari fakta tersebut ada dua kemungkinan yang terjadi, pertama remaja tadi terpengaruh oleh teman-temannya atau bahkan teman-teman remaja tersebut dipengaruhi oleh diri remaja tersebut sehingga akhirnya mereka menjadi perokok. ${ }^{18}$

Salah satu hal yang menyebabkan remaja merokok karena ingin mendapat pengakuan dari teman-temannya, sehingga remaja belajar cara merokok atau mencoba merokok pada saat berkumpul bersama teman-temannya. ${ }^{15}$ Penerimaan oleh kelompok sebaya merupakan hal yang penting, bisa mengikuti dan tidak tampak beda dengan yang lainnya merupakan motif yang mendominasi sebagian besar perilaku sosial remaja. Setiap perbedaan dengan rata-rata teman sebayanya akan menimbulkan kecemasan. Kecemasan sering juga timbul karena merasa tidak aman dalam berteman dan ketakutan akan ditolak dalam pergaulan. ${ }^{19}$

Dari hasil penelitian terdapat hubungan antara keluarga yang merokok dengan perilaku merokok pada siswa/i SMPN 33 Kota Pekanbaru. Siswa/i yang memiliki keluarga yang merokok maka akan berisiko 2,4 kali untuk berperilaku merokok juga dibandingkan dengan siswa/i yang tidak mempunyai keluarga yang merokok. Penelitian ini sejalan dengan penelitian Dwi tahun 2012 yang menunjukan ada hubungan antara dukungan keluarga dengan perilaku merokok mahasiswa Universitas
Hasanuddin Kota Makassar. Dukungan dari keluarga terdekat penting bagi seseorang dalam bertindak dan mengambil keputusan. ${ }^{18}$ Keluarga mempunyai peran yang sangat strategis membentuk sikap remaja. Keluarga merupakan sekolah dan tempat pembelajaran pertama seorang remaja. Orangtua merupakan teladan bagi anak- anak, interaksi yang mendalam antara orang tua dan anak, melahirkan karakter yang mirip. Orangtua adalah model bagi seorang anak (remaja). Orangtua berperan penting dalam menginisiasi remaja merokok. Orangtua merokok dianggap sebagai bentuk legitimasi merokok bagi anakanak mereka. ${ }^{14}$

Dari hasil penelitian terdapat hubungan antara uang saku dengan perilaku merokok pada siswa/I SMPN 33 Kota Pekanbaru. Rata-rata uang saku dari siswa/I yang yang berperilaku merokok adalah Rp. 12.505,00 lebih tinggi dibandingkan rata-rata uang saku siswa yang tidak berperilaku merokok yaitu Rp. 6610,00. Hasil penelitian ini sejalan dengan penelitian Rina tahun 2006, yaitu siswa yang mempunyai uang saku berlebihan berisiko 2,3 kali untuk berperilaku merokok. Uang saku yang diberikan dengan berlebihan dan tidak bijaksana akan dapat menimbulkan masalah yaitu remaja menjadi boros, remaja tidak menghargai uang dan remaja malas belajar, sehingga remaja cenderung tergoda dan merasa kecanduan dengan rokok karena harga rokok yang tidak mahal dan boleh membeli perbatang. ${ }^{20}$ Hasil penelitian zahro tahun 2006 juga menunjukan ada hubungan antara uang saku dengan praktik merokok responden. Hal ini sesuai dengan teori Green yang menyatakan bahwa uang saku merupakan faktor pemungkin (enabling factor) yang memungkinkan responden untuk membeli rokok dan selanjutnya melakukan praktik merokok. ${ }^{21}$

\section{KESIMPULAN}

Proporsi Siswa/i yang merokok di SMPN 33 Kota Pekanbaru adalah sebanyak 89 orang $(27,5 \%)$ dari 324 orang. Pengetahuan, iklan rokok, keluarga merokok, teman sebaya perokok dan uang saku merupakan determinan 
perilaku merokok Siswa SMPN 33 Kota Pekanbaru. Diharapkan pihak sekolah membuat kebijakan KTR (Kawasan Tanpa Rokok) di sekolah serta memberikan sanksi kepada siapapun yang merokok di lingkungan sekolah sekalipun guru yang melakukannya dan bekerjasama dengan instansi kesehatan agar dapat memberikan penyuluhan tentang bahaya rokok agar pengetahuan siswa/i SMPN 33 Kota Pekanbaru meningkat sehingga tidak berperilaku merokok. Diharapkan pemerintah melarang iklan rokok disembarang tempat seperti di tempat-tempat umum yang dapat mempengaruhi perilaku siswa/i untuk merokok. Orang tua harus memantau kegiatan anaknya dan mengetahui teman bergaul anaknya karena jika temannya tersebut bergaul atau berteman dengan orang yang perokok maka ia akan cenderung meniru perilaku temannya yang perokok tersebut. Orang tua juga seharusnya tidak memberikan contoh yang negatif kepada anaknya yaitu dengan tidak merokok di depan anak-anaknya. Orang tua sebaiknya jangan terlalu berlebihan dalam memberikan uang saku kepada anaknya dan memantau uang saku yang diberikan kepada anaknya tersebut agar uang saku tersebut tidak salah digunakan seperti untuk membeli rokok bahkan narkoba. karena banyak kasus anaknya yang memakai narkoba awalnya dimulai dari menghisap rokok.

\section{DAFTAR PUSTAKA}

Nasution. Perilaku Merokok Pada Remaja. [Skripsi]. Medan: Universitas Sumatera Utara; 2007.

Manique. Menghindari Merokok. Jakarta: PT Balai Pustaka; 2004.

Fuadah M. Gambaran faktor-faktor yang mempengaruhi perilaku merokok pada mahasiswa laki-laki fakultas teknik UNJ. [Skripsi]. Depok: Universitas Indonesia; 2011.

Bastable, S. Essentials of patient education. Washington DC: Jones and Bartlett Publishers; 2006.

Muhammad, J. Pembunuh Berbahaya Itu Bernama Rokok,. Sleman: Riz'ma; 2009.
BBC. 2014. Perokok Dunia Capai Satu Miliar. (diakses 22 juni 2014) http://www.bbc.co.uk/indonesia/majalah /2014/01/140108_majalah_la in_perokok_dunia.shtml.

Kemenkes RI. Riset Kesehatan Dasar (Riskesdas) 2013. Jakarta: Badan Penelitian dan Pengembangan Kesehatan Kementerian Kesehatan RI; 2013.

Andika, D., Khairsyaf, O. \& Pertiwi, D. Hubungan Pengetahuan Dengan Kejadian Merokok Pada Pelajar SMPN 1 Pariaman. Jurnal Kesehatan Andalas. 2016; 5 (2): 361-364.

Sarino, Ahyanti. Perilaku Merokok Pada Siswa Laki-Laki SMP. Jurnal Ilmu Keperawatan. 2012; 8(2): 1-14.

Ali, M. Pengetahuan, Sikap, dan Faktor Psikologis Berhubungan dengan Perilaku Merokok pada Pegawai Poltekkes Kemenkes Jakarta III. Jurnal Ilmu dan Teknologi Kesehatan. 2014;2:, 101-10..

Alamsyah, A. \& Novianto. Determinan Perilaku Merokok Pada Remaja. Jurnal Endurance. 2017.2(1); 25-30.

Wulandari, A., Rahman, F., Marlinae, L. \& Arifin, S. Persepsi Tentang Peringatan Bergambar Pada Kemasan Rokok. Jurnal Media Kesehatan Masyarakat Indonesia. 2016; 12(1): 14-20.

Rifqi A. Fattah, D. S. Faktor yang Berhubungan dengan Perilaku Merokok pada Remaja. Jurnal BMKMI. 2013; 2 (1): 3-11.

Rachmat, Muhammad., Thaha, Ridwan Mochtar., Syafar, M. Perilaku Merokok Remaja Sekolah Menengah Pertama. Jurnal Kesehatan Masyarakat Nasional. 2013; 7(11): 502-508.

Widiansyah, M. Faktor-Faktor Penyebab Perilaku Remaja Paser Utara Latar Belakang. Ejournal Sosiologi Unmul . 2014; 2 (4): $1-12$. $\mathrm{http}$ //ejournal.sos.fisip-

unmul.ac.id/site/wpcontent/uploads/2014/10/penting (10-0214-12-04-55).pdf

Kemenkes RI. Pedoman Pengembangan Kawasan Tanpa Rokok. Jakarta: Pusat 
Promosi Kesehatan Kementerian Rina Yulviana. Faktor-Faktor yang

Kesehatan RI; 2011.

Ramadhani, V. \& Hidayat, A. Smoking Behavior Study on Teenagers '. Jurnal Siasat Bisnis. 2009; 13 (1): 61-76.

Muliyana, D. \& Thaha, I. L. M. Faktor yang Berhubungan dengan Tindakan Merokok Pada Mahasiswa Universitas Hasanuddin Makassar. 2013; 109-119.

Dwi, S. C. Pertumbuhan Perkembangan Anak dan Remaja. Jakarta: CV Trans Info Media; 2011.

Berhubungan dengan Kebiasaan Merokok pada Remaja Putra Kelas X dan XI di SMA Negeri 6 Pekanbaru. Jurnal Kesehatan Komunitas. 2013; 2(6): 278282.

Shaluhiyah, Z., Karyono \& Noor, F. FaktorFaktor Yang Berpengaruh Terhadap Praktik Merokok Pada Remaja Sekolah Menengah Pertama di Kabupaten Kudus. Jurnal Promosi Kesehatan Indonesia. 2006; 1 (1):1-8.

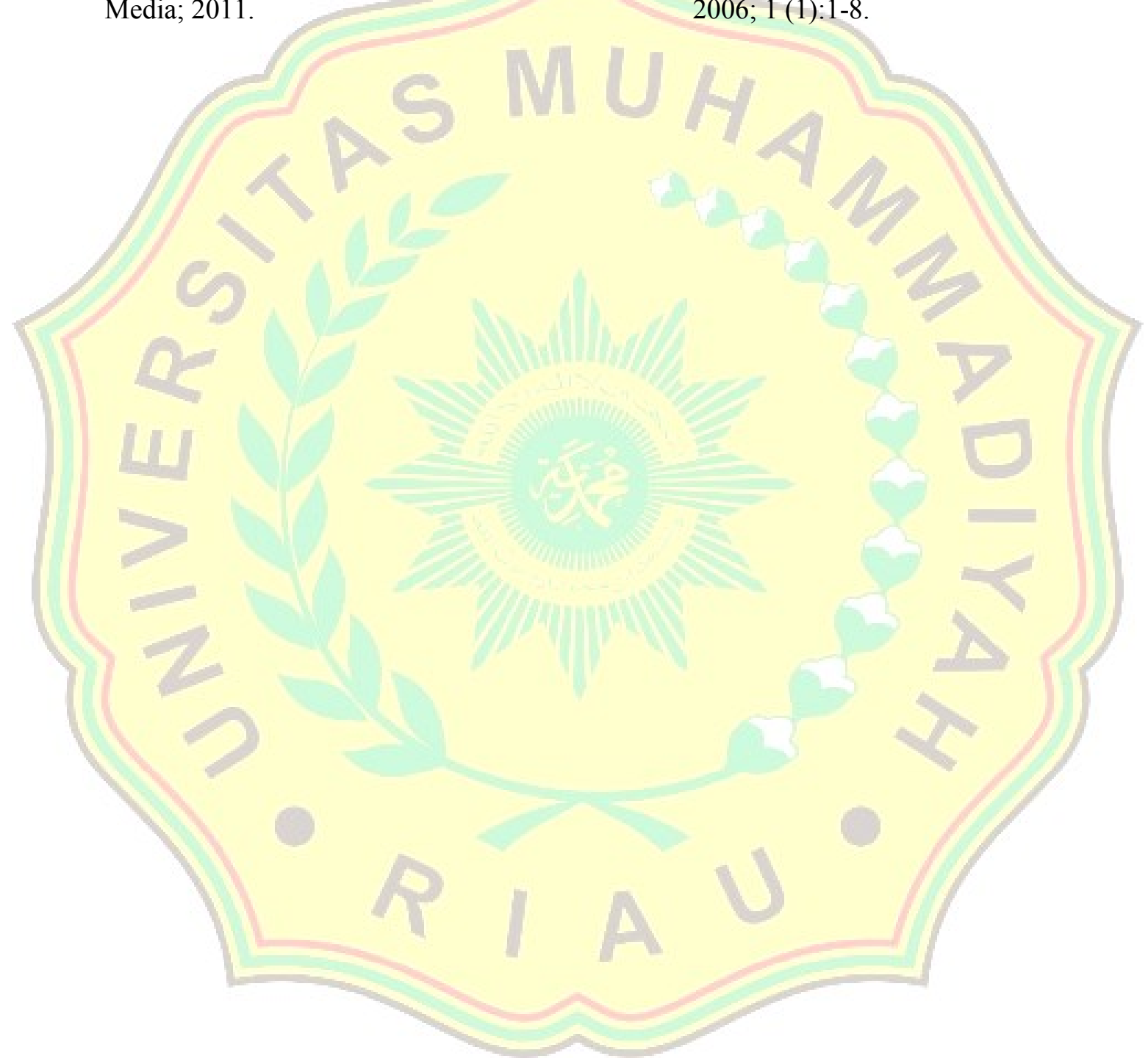

